University of Nebraska - Lincoln

DigitalCommons@University of Nebraska - Lincoln

Textile Society of America Symposium

Proceedings

Textile Society of America

2020

The souls of the dead: images woven in women's clothing of the

Jalq'a cultural area (south-central Bolivia)

Veronica Cereceda

Follow this and additional works at: https://digitalcommons.unl.edu/tsaconf

Digitart of the Art and Materials Conservation Commons, Art Practice Commons, Fashion Design

Commens, Fiber, Textile, and Weaving Arts Commons, Fine Arts Commons, and the Museum Studies

detwerkns

Logo

This Article is brought to you for free and open access by the Textile Society of America at

DigitalCommons@University of Nebraska - Lincoln. It has been accepted for inclusion in Textile Society of America

Symposium Proceedings by an authorized administrator of DigitalCommons@University of Nebraska - Lincoln. 


\title{
The souls of the dead: images woven in women's clothing of the Jalq'a cultural area (south-central Bolivia)
}

\author{
Verónica Cereceda
}

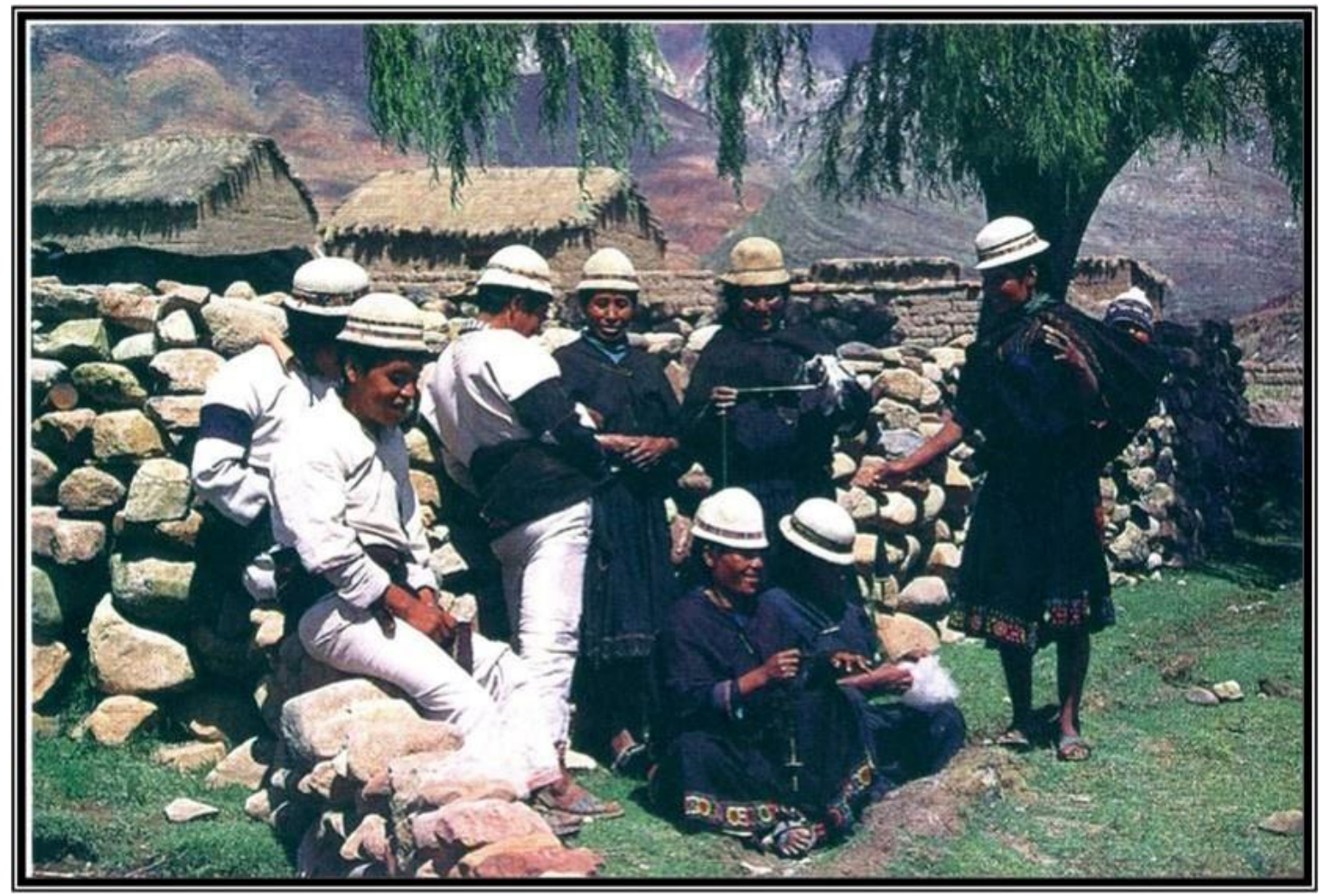

Figure 1. Jalq'a people in south central Bolivia

In textile designs created by the women of the Jalq'a cultural area in south-central Bolivia, we find, among the other personages that accompany them, figures that incarnate the souls of the dead. This brief essay asks how they have been materialized by the weavers, these beings whose nature it is to be, in particular, invisible.

It is possible to consider the Jalq'a as an ethnic group, although they have neither a formal structure nor community leadership that encompass them all. The name refers to an original indigenous population who base their identity on many diacritical shared traits (clothing, music, dances, rituals, origin myths) and, especially, on their ethnonym ' Jalq' $a$ " with which they identify themselves and are recognized by neighboring groups.

Published in Hidden Stories/Human Lives: Proceedings of the Textile Society of America 17th Biennial Symposium, October 15-17, 2020. https://digitalcommons.unl.edu/tsaconf/ Copyright @ 2020 Verónica Cereceda doi: $10.32873 /$ unl.dc.tsasp.0110 
Numerous communities, many of which emerged from ex-haciendas converted today into agrarian unions ${ }^{1}$ and remnants of ayllus ${ }^{2}$ with this identity, extend across the central and northern parts of the Department of Chuquisaca and a small part of the eastern Department of Potosí.
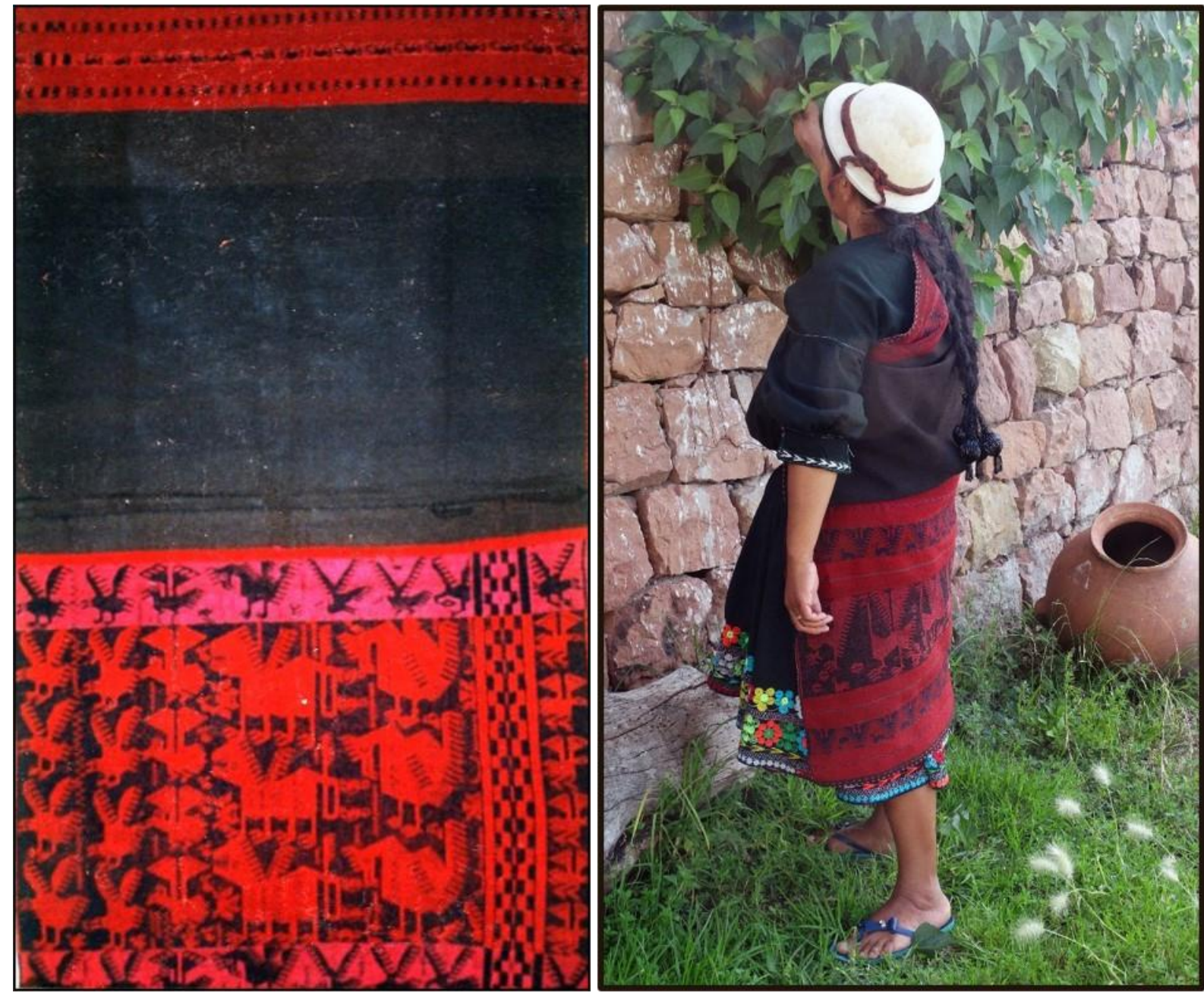

Figure 2. Aqsu and a woman wearing the Aqsu

The principal garment worn by Jalq'a women, that which most directly expresses their identity, is the Aqsu, a garment of PreColumbian origins which has transformed, in this region of southcentral Bolivia, into a kind of mantle covering the back, bound at the waist by a woven band.

Among its plain-weave areas, the $a q s u$ has two bands of woven patterning, one above, a larger one below, up to the edge of the garment. These patterned areas are called pallay, in Quechua, a term that both designates the technique, by which the designs are created, and the designs

\footnotetext{
${ }^{1}$ In Bolivia, an Agrarian Union, Sindicato Agrario is a community-managed organization in change of production, regulating its internal and external relationships in interaction with regional government. Agrarian unions were first formed after the Chaco War (1932 - 1935) and play an important role in Bolivian history and politics.

${ }^{2}$ Ayllus: a traditional Andean social structure, which takes different forms.
} 
themselves. These pallays ${ }^{3}$ have very particular characteristics that distinguish the Jalq'a women from the women of other neighboring groups, who use a garment of similar format.

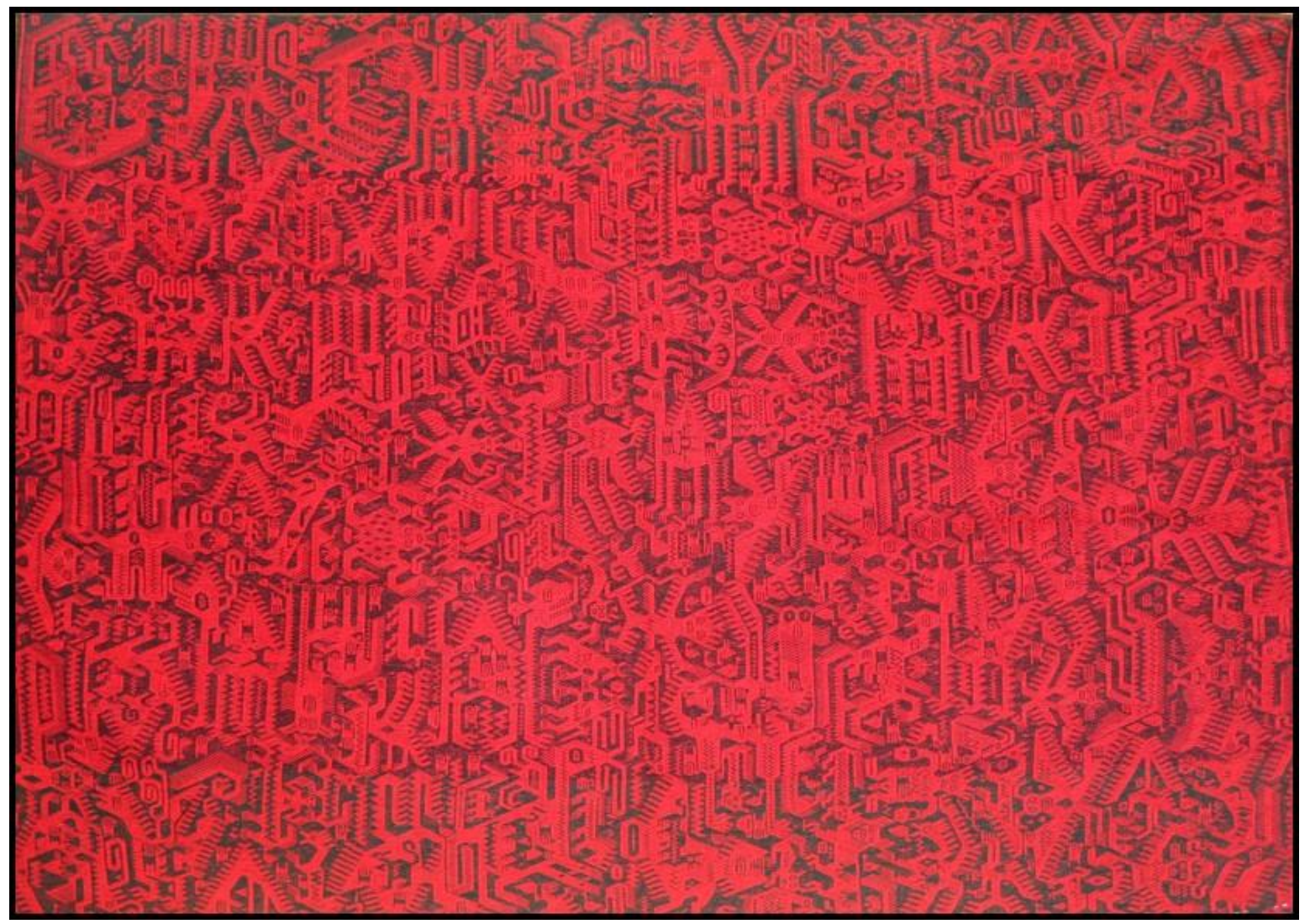

Figure 3 - Example of a Jalq'a pallay

The images, produced by crossing the two sets of warps of different hues that appear on the two faces of this textile, have been woven purposefully to achieve effects of darkness and disorder, without spatial structures that would organize the figures. The forms and outlines of the different personages cooperate in giving the impression that they could each be almost interlaced with the others. A motley group, difficult to perceive at first glance. These, and other sensory characteristics of this art, already impart semantic content that locates this space of the pallay as forming part of the world of the "interior" interior of the earth, of the high hills, of the great rocky peaks and the deep caverns. The world called $u k h u$ pacha in Quechua.

\footnotetext{
${ }^{3}$ We write some words in Quechua with the Spanish plural of "s," although it is not used in this language, to make the reading more accessible.
} 


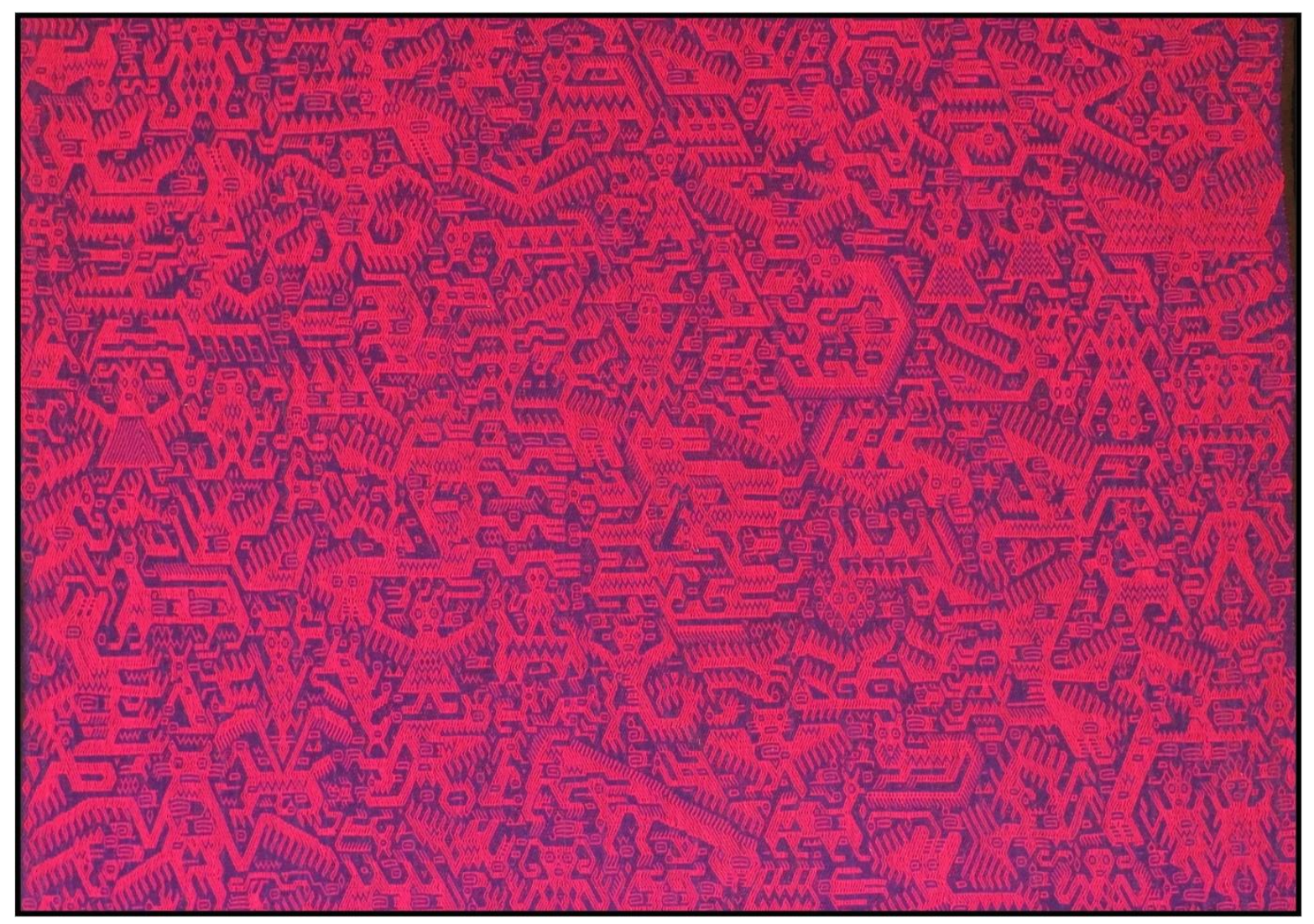

Figure 4: Another example of pallay. Ukhu pacha or Andean Hell.

Precisely, ukhu pacha was the term interpreted and selected by the Catholic Church to give a native term to the European Hell which came to the Andes with colonization.

In the current religious concepts of the Jalq'a, this interior space is not accessible to human experience. Anyone who might get close or be able to penetrate into it -perhaps seized by the demons- would lose consciousness and become insane. But the weavers, as if they were the priestesses of a diabolic cult, make it perceptible in their designs.

The topic that we address in this text is a personage that, according to the women, who are those who weave it, populates this infernal space among several others. The most important figures on the iconic level of the pallays are those called "khurus." These are always animals that are not humanized, strange, with anatomies impossible in the animals of everyday experience, who constitute in the woven images a special category of the "wild," impossible to domesticate. These encompass, along with completely imaginary beings, animals of the tropical rainforest considered to be "savage" or "fierce," but including some special physical characteristic: wider bodies, very long necks, etc.

The khurus, like everything of the interior, are considered to belong to the demonic sphere of the world, ukhu pacha. There are many of them, and a great variety of species. These constitute a set 
of beings that exist in Jalq'a thought, that the weavers materialize in their pallays. The term khuru, in the Colonial or more recent dictionaries, is only translated (kuru) as meaning "critter" (bicho) or referring to some wild animal, without specifying the particular, more complex characteristics of the khurus that populate the woven Hell.
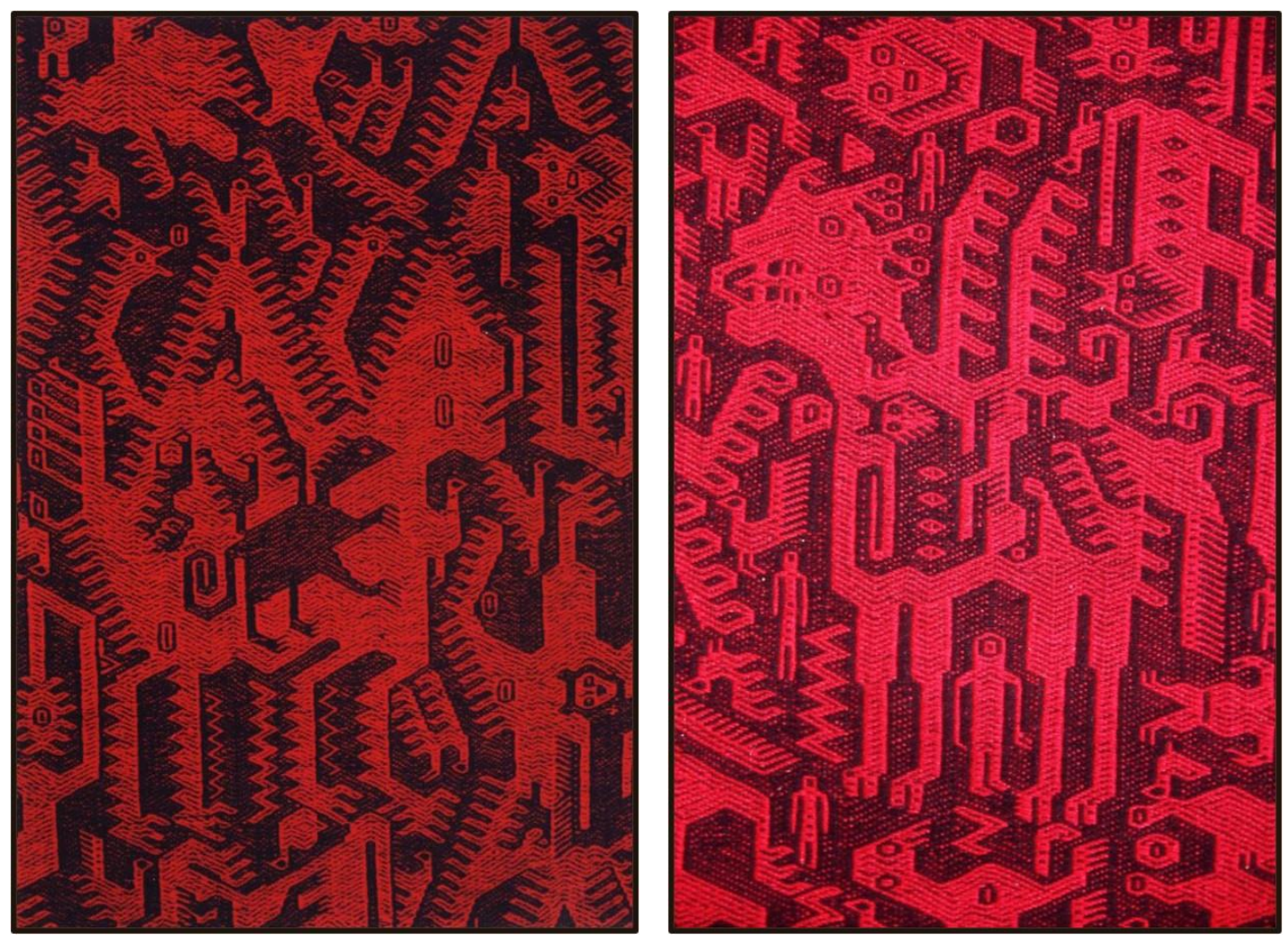

Figure 5: Examples of khurus, mythic animals not perceptible in everyday experience

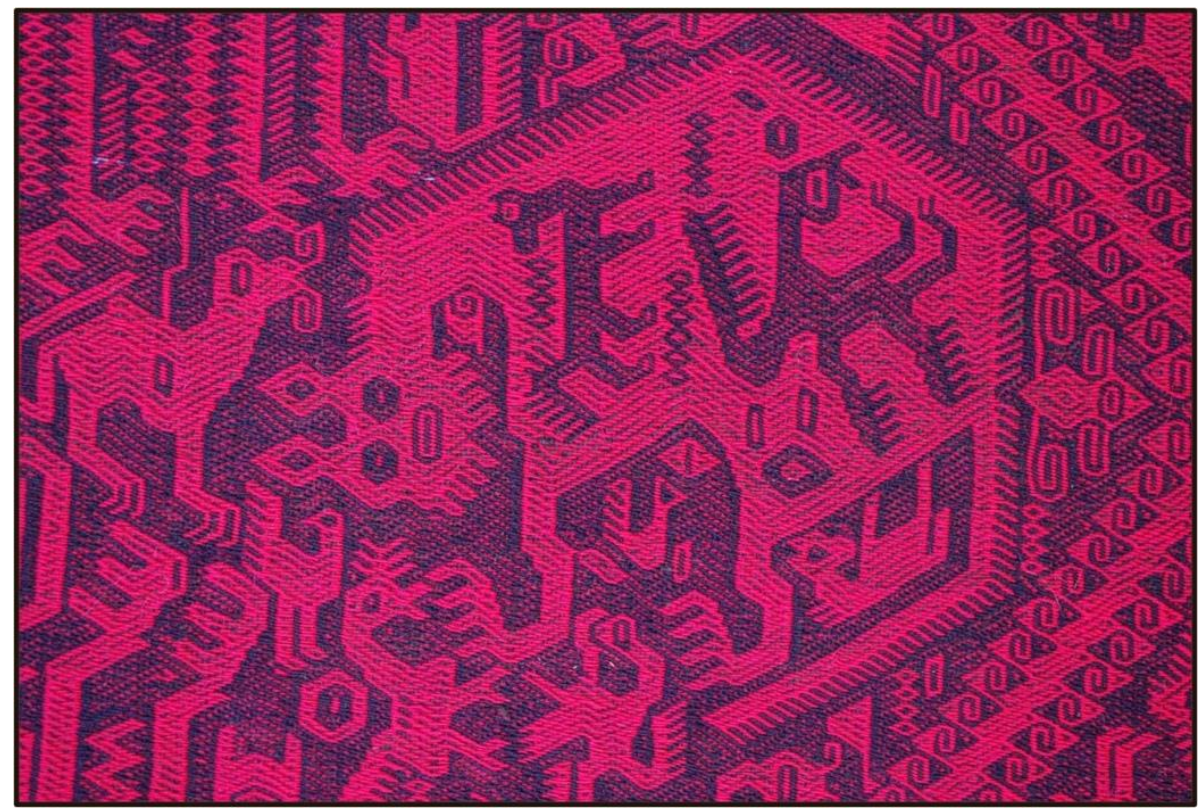

Figure 6. Uñas, offspring of diverse species that appear in the interior of the khuru, in this case in the form of a monkey. 
It is interesting to observe that among several of these mythic personages frequently appear a second type of figures that make them seem as if they were pregnant. The weavers mention them as "uñas" (Quechua: offspring of an animal) or, even as "wawas" (a word used instead for human infants). Therefore, the khurus are manifesting their nature as fecund beings. In the uñas, we thus have a second type of figures that populate the Andean space of the interior.

A third entity, or being, inhabiting ukhu pacha, is naturally the devil or demon, supay or saqra in Quechua. They are woven and made visible with certain attributes that differentiate them from Christian devils, represented in numerous images on the walls of the Colonial churches of Parroquias de Indios or in diverse prints and engravings that circulated profusely to evangelize the native population.
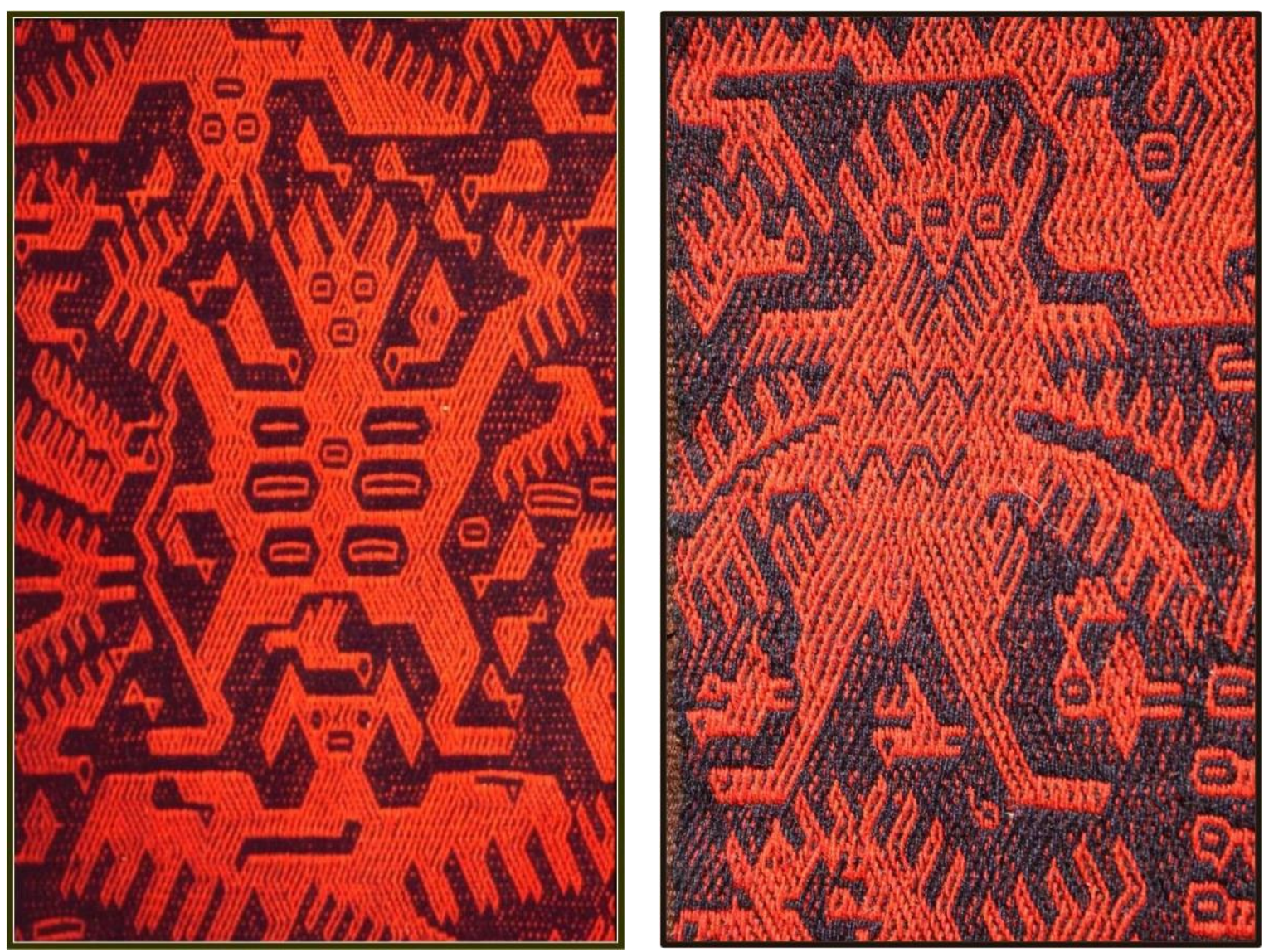

Figure 7: Andean demons, Supays or Saqras, in Quechua. The horns sometimes appear in the form of crowns, reminiscent of the imagery of the ancient center of Tiwanaku. We note that they are also in part birds, with wings in the place of arms.

But our theme this time is a fourth personage, far more simple, smaller: that which makes manifest the presence in this infernal design of the souls of the dead. ${ }^{4}$ Sometimes, in a pallay

\footnotetext{
${ }^{4}$ In Jalq'a thought, there are several types of souls, some which go to heaven, others which haunt on earth, and others which return for All Saints day in November. Those woven in the Pallays correspond to souls celebrated in
} 
there are many souls present, although it is not easy to distinguish them among other personages that are larger and attract the eye.

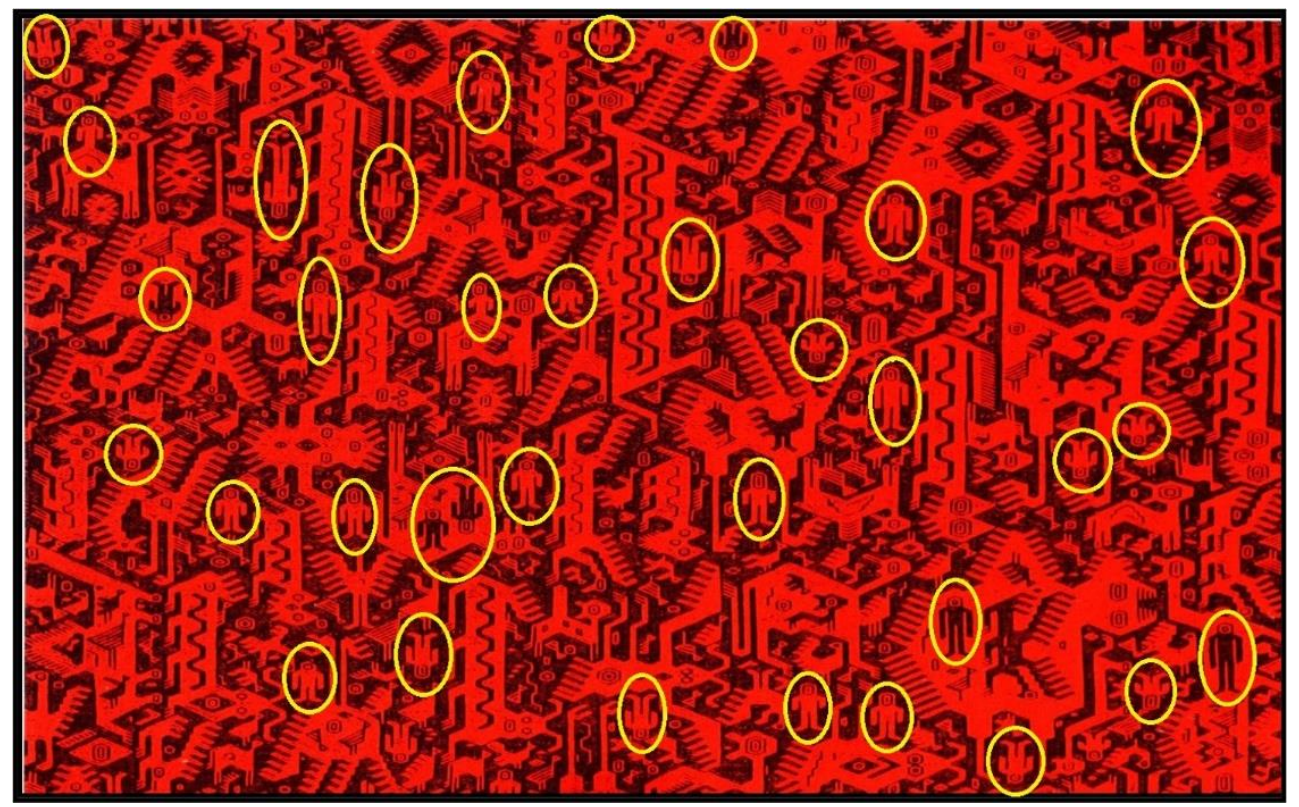

Figure 8: Almas in profusion, almost imperceptible in a pallay.

How have they been conceived and made palpable by those who weave, these beings that in human experience are by nature intangible?

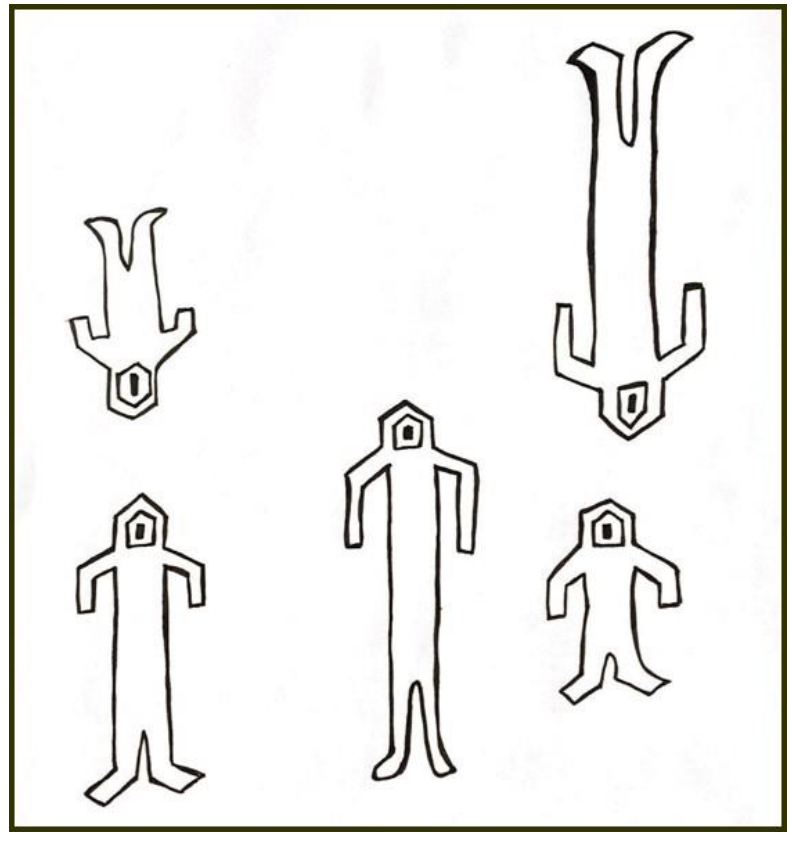

Figure 9: Outlines of almas.

Carnival, those of persons who have had a violent death or died in places far from their residence, considered to belong to the Andean demonic realm. 
They have a semi-human form that differentiates them from the other beings that populate pallay. They stand static, rigid, but that which most peculiarly defines them is that strange head, which we could say is reminiscent of a diving helmet, blunt, mouthless, and almost always with a single eye. We note that this humanized figure has no attributes or marks defining ethnicity.

What attracts us in this visible materialization, so much simpler than the extraordinary wild animals and the complex demons? It is the attempt to understand how the Jalq'a weavers have been able to give palpable life to these beings whose nature is only spirit.

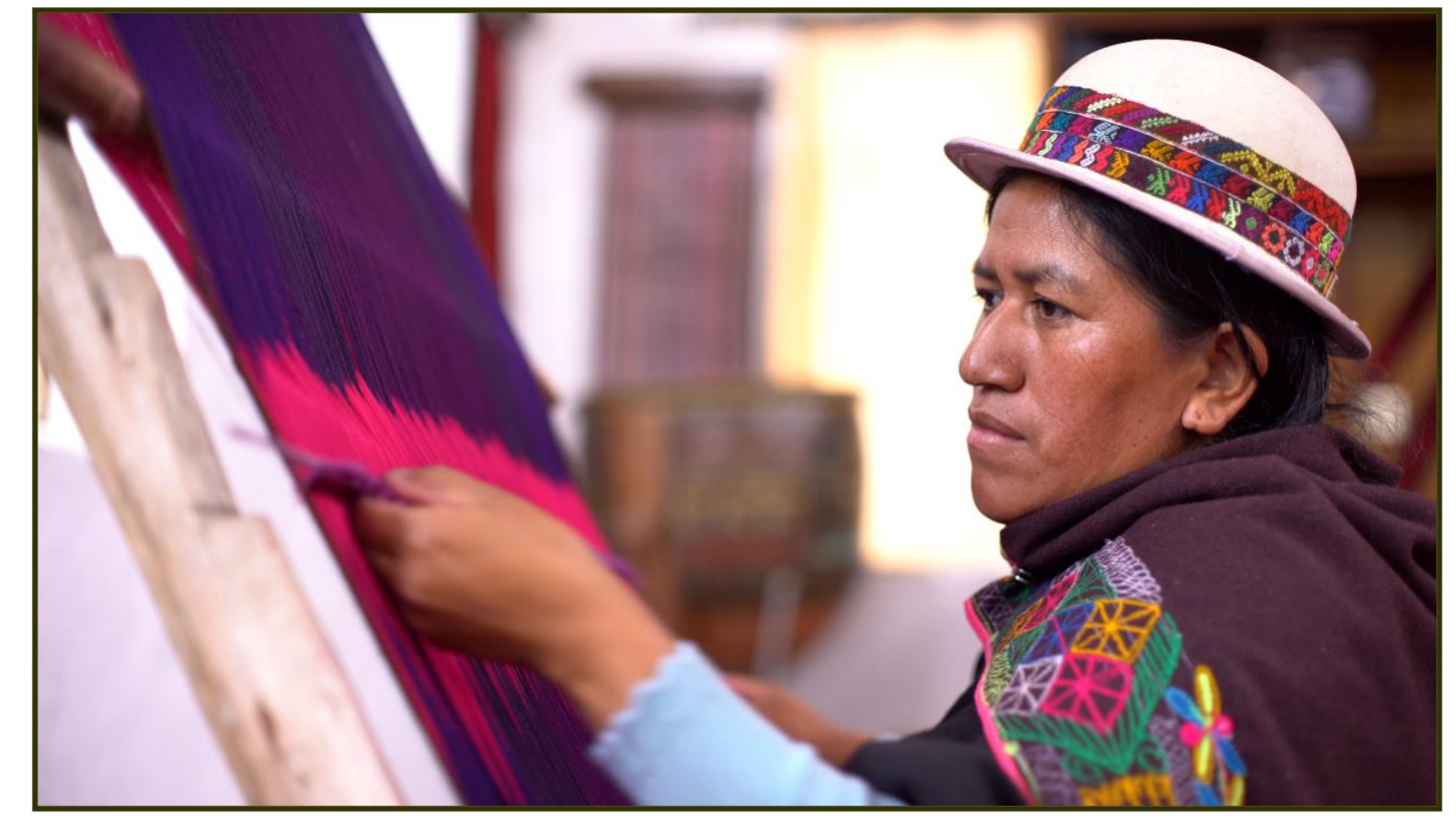

Figure 10. Jalq'a weavers. They had to think and dream, along with so many other weavers of this culture, about what might be the possible corporeality of souls.

What did they work from? Their images needed to be created and socialized as "souls" by the many women who recognized them in this particular form and these strange heads, and who have been weaving them for generations, converting them, thus, in an icon of identity on the feminine garments of this cultural region.

In two Jalq'a aqsus, the oldest ones we know of from about 120 years ago, the figures of the souls do not appear. Nor are they in the numerous photographs in museums or private collections that preserve very beautiful and fine Jalq'a textiles -with a certain formal similarity among them- that we suppose arose years later, after the Agrarian Reform of 1953 that transformed the system of large haciendas into Agrarian Unions, with a profound effect on the communities. 
From the 1980s, more or less, in the last century -without a precise date of its creation- we have $\mathrm{e}^{5}$ a first aqsu with a pallay that shows a small scene with personages that more recent weavers interpret as souls.

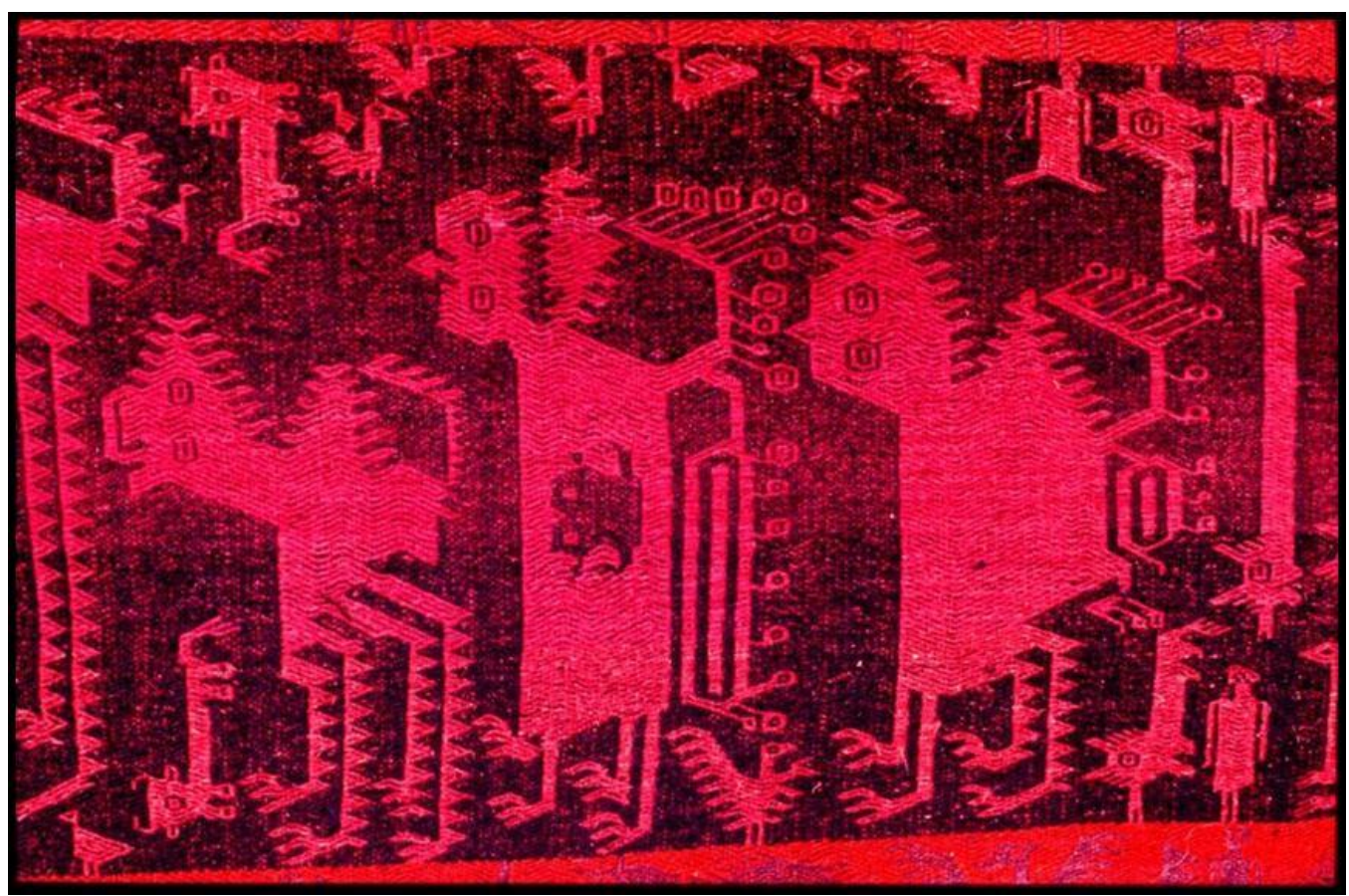

Figure 11. Two humanized figures appear in the upper right part of this pallay, separated by a Khuru, in this case an African lion that is supposed to inhabit the tropical rainforest of Amazonía, substituting for the image of the American jaguar.

Their bodies appear more elastic and less canonical than the figures of souls woven more recently, but it is already possible to recognize their strange head.
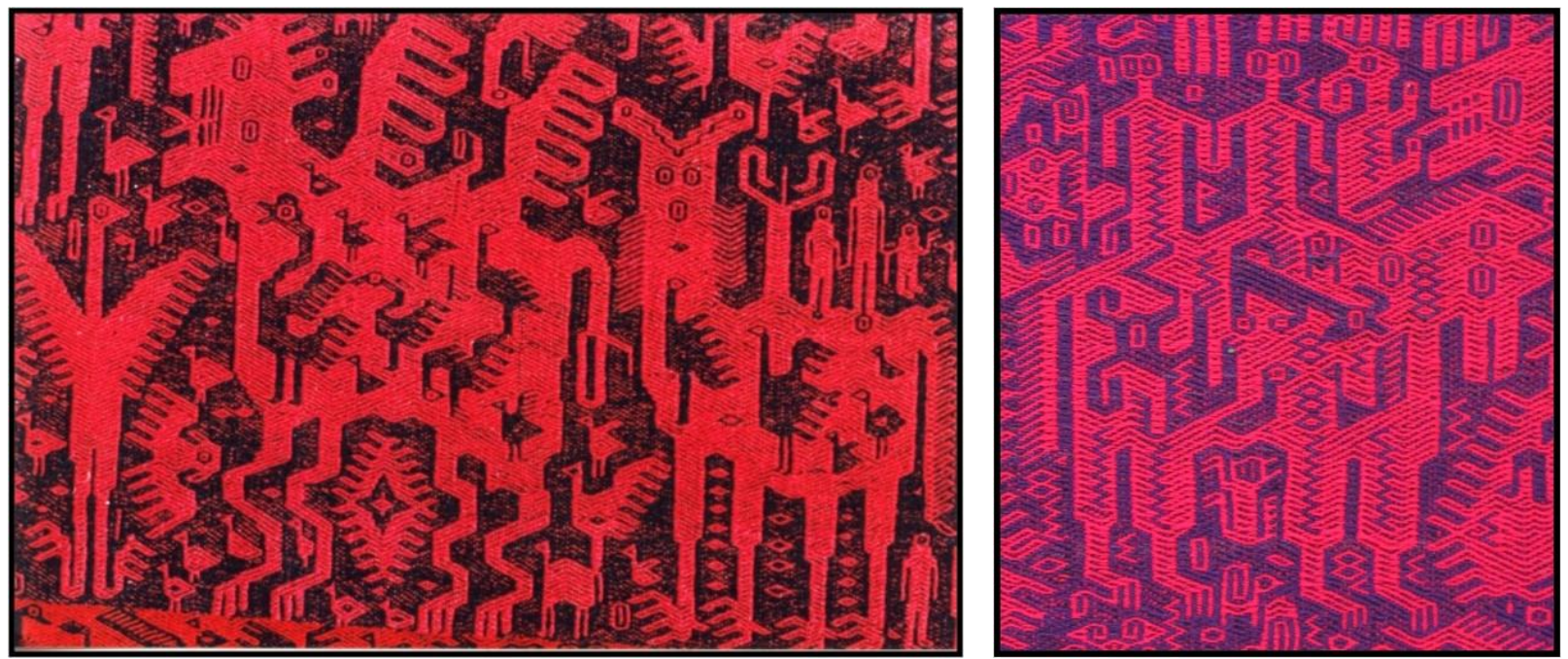

Figure 12. Details showing the souls standing on top of the Khurus.

\footnotetext{
${ }^{5}$ Museum of Indigenous Art, of the ASUR Foundation.
} 
What do they teach us, what do these souls woven in the pallays tell us about Jalq'a mythic thought? The women, who are the weavers, have situated them in the interior space, in $u k h u$ pacha, that is to say in the Andean Hell, a place already defined as fertile by the presence of offspring in the interior of the khurus. The souls often appear is close proximity to those personages. Frequently, they mount them.

The weavers take advantage of this situation to make manifest the lightness of these beings -they go barely posed on the back of the khurus- as, having abandoned their bodies, they no longer have weight.

The creation of this strange personage by the Jalq'a weavers does not appear to have graphic antecedents. The devils, although very different from those we have been able to observe in the woven designs, are, nonetheless, as we mentioned before, represented in diverse Colonial and even Republican images.

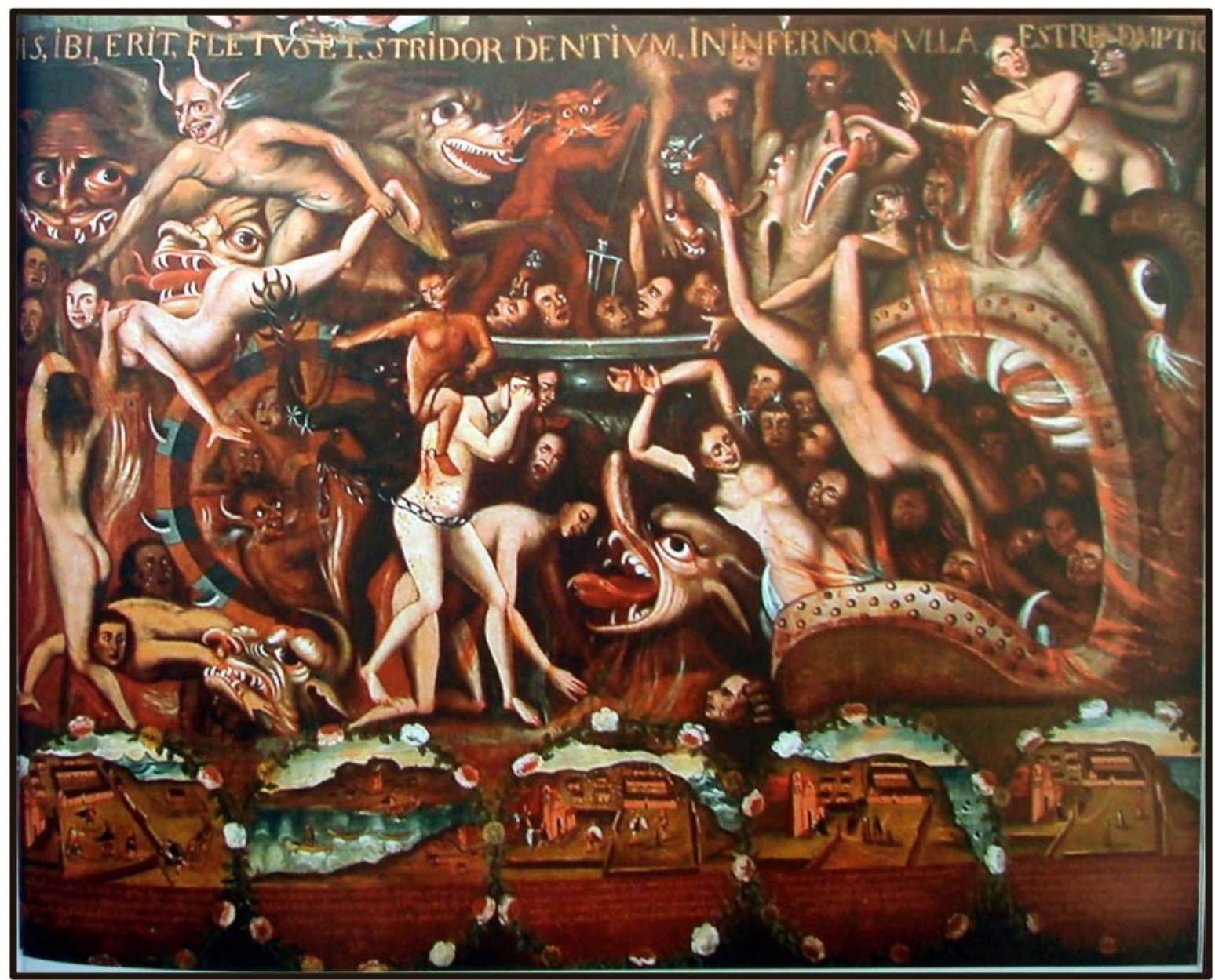

Figure 13. Hell in a mural in the Colonial church of Caquiaviri, on the Bolivian high plateau: Devils, strange animals and condemned souls. 
As can be observed, in the reproduction above addressing the End of Life (according to the Catholic credo), there are only demons, strange animals and condemned souls. These souls, per $s e$, are not represented. Whereas the devils, on the other hand, although very transformed in the weavings and with other attributes, can be traced to these figures of demons that arrived with European conquest.

For the souls, however, we have not found at present representations in the Colonial arts that could have inspired their visualization, nor other Bolivian textiles that bear a materialized figure of this spiritual being.

We would have to consider, perhaps, some figures in rock art, that may resemble those woven, without being necessarily an incarnation of these personages.

Thus, it is possible to affirm that this constitutes an artistic, visual, sensual contribution by the weavers, that enters the regional religious experience through the pallays. That is to say, a true ethnogenesis, a modern creation of culture in images achieved by the women.

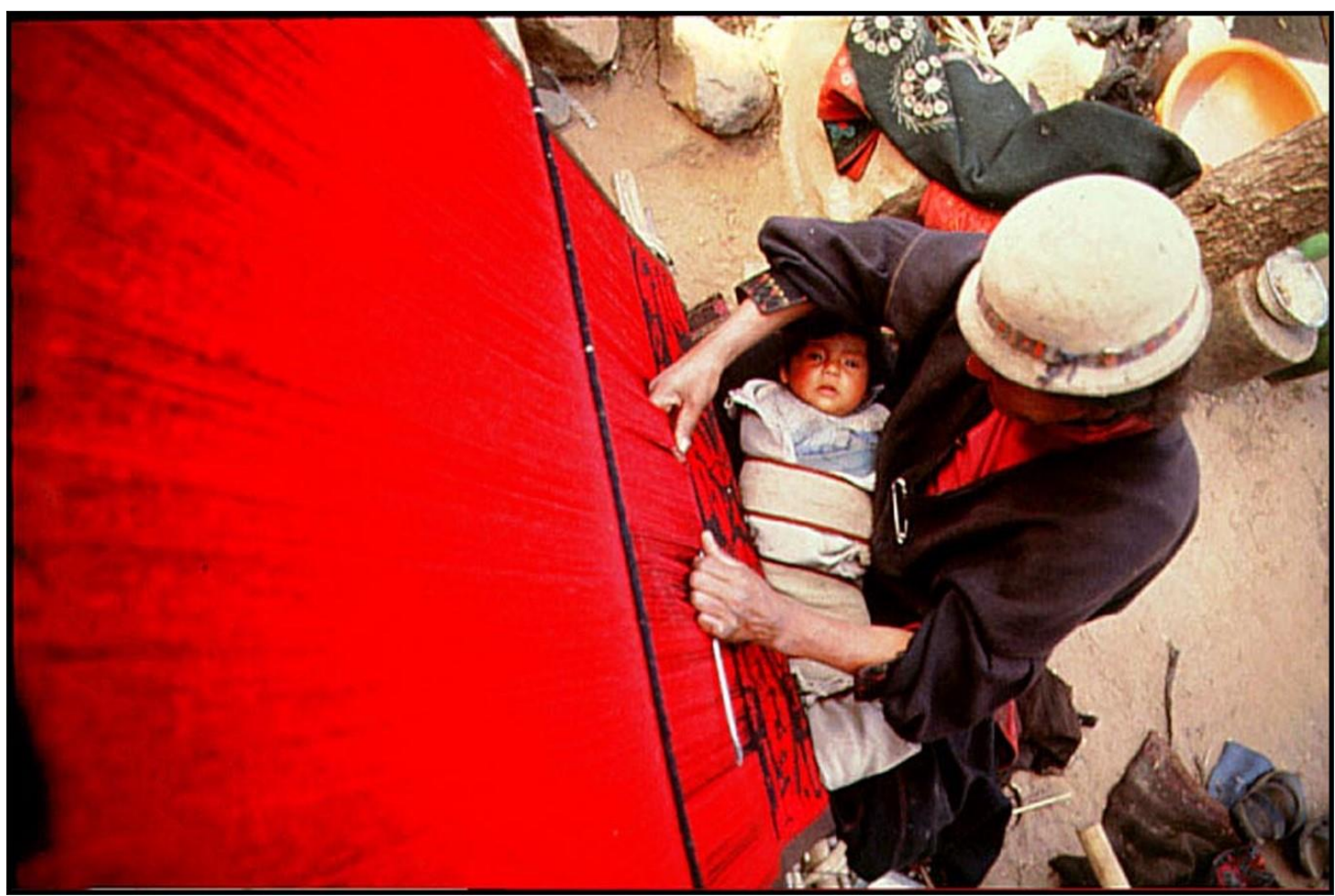

Figure 15. Weaver at her loom.

A second, very interesting contribution is suggested to us by the presence of souls living in $u k h u$ pacha, with the other personages, khurus and supays or demons. Each type of figure is iconically well differentiated from the others: the souls of the dead, khurus with their uñas, offspring, and devils, saqra or supays. 
It is impossible to mistake them, but nonetheless, in referring to their designs, those who weave only mention them as "Supay Pallay," that is to say, design and techniques of the demon. Thus, a doubt arises, are there four beings, including the $u \tilde{n} a s$, with their own personalities, existing together in the Andean Hell? ¿Or rather one principal deity, unique, a supernatural power of the depths -"that of supay", we might say- which the weavers show to us broken down into its three possible constituent facets?

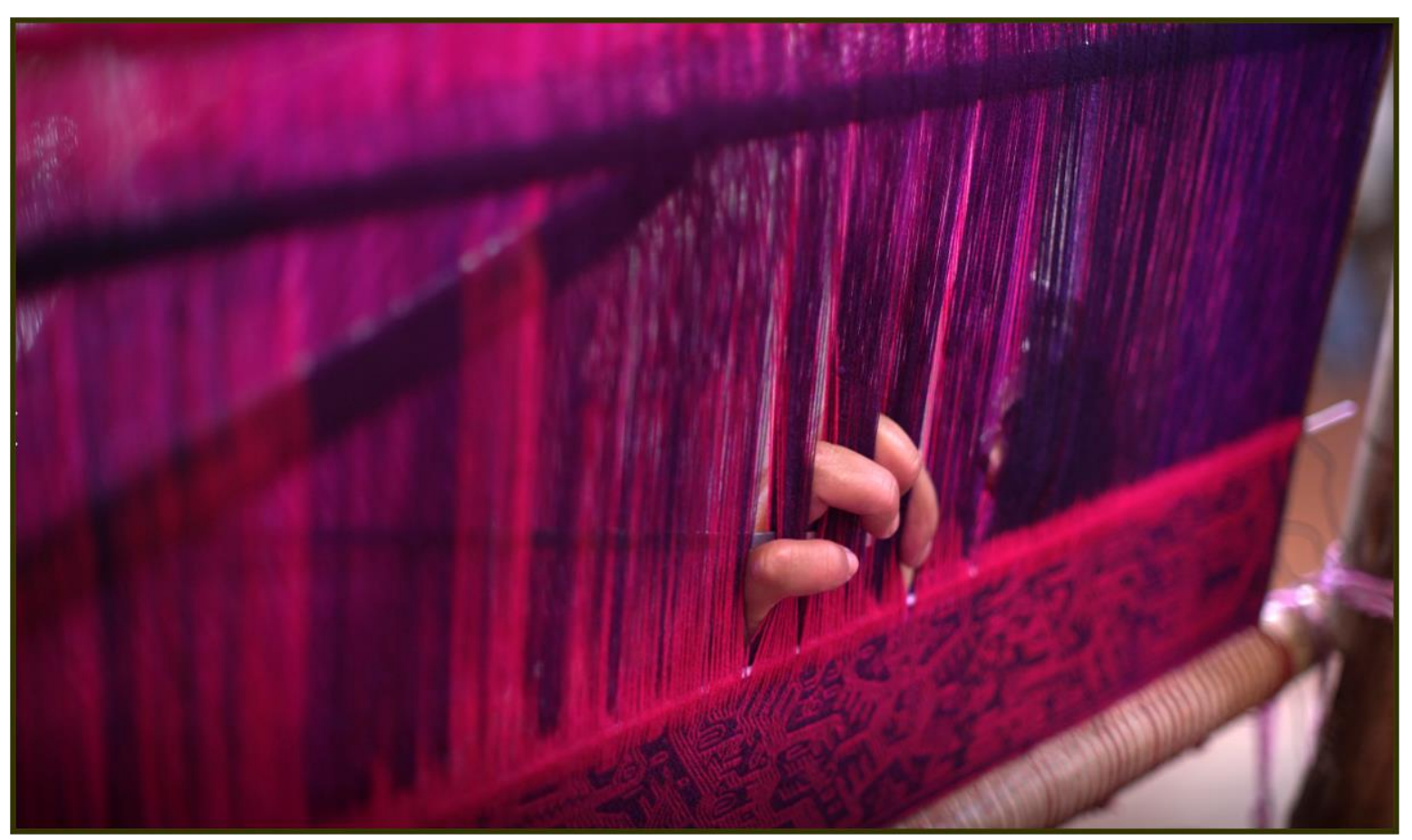

Figure 16: The loom seen from behind: We can observe the weaver's fingers working with the yarns.

This mythic issue appears to be another ontological contribution: the visualization of this ambiguity, valid in Andean thought, to be and yet not be a single entity, which is put forward in the woven images. The women have it in mind, necessarily, as they are interlacing the yarns. We have not found it so clearly formulated in other media or vehicles of this culture.

So small and insignificant, indistinguishable when the woman has put on her outfit and is walking in it, the souls are there exerting their ritual action as much over the body that they encompass as over the world that surrounds it. But this power -force that emanates from these figures- would be the subject of another essay. 